\title{
Applications of 2,4,5-TP, 3,5,6-TPA, and Combinations Thereof Increase Lychee Fruit Size and Yield
}

\author{
Raphael A. Stern ${ }^{1}$ \\ MIGAL, Galilee Technology Center, P.O. Box 90000, Rosh Pina 12100, Israel
}

Daniel Stern

Kibbutz Lavi, Lower Galilee 15267, Israel

Moshe Harpaz

Moshav Almagor 12340, Israel

\section{Shmuel Gazit}

The Kennedy-Leigh Centre for Horticultural Research, The Hebrew University of Jerusalem, Faculty of Agriculture, Rehovot 76100, Israel

Additional index words. abscission, auxin, fruitlet, Litchi chinensis

\begin{abstract}
Application of TP as Tipimon ${ }^{\circledR}$ or TPA as Maxim ${ }^{\circledR}$ at the young fruitlet stage significantly increased yield in three lychee (Litchi chinensis Sonn.) cultivars: 'Mauritius', 'Floridian', and 'Kaimana'. Application of TP followed by TPA a week later increased yield more than did either substance alone. In all experiments, TPA increased fruit size and weight, relative to both controls and TP-treated trees. The increased yield did not prevent the increase in fruit size. Use of sprays of TPA may be an effective way of satisfying the market demand for large lychee fruit. Chemical names used: 2,4,5-trichlorophenoxypropionic acid (TP); 3,5,6-trichloro-2-pyridyloxyacetic acid (TPA).
\end{abstract}

Size is an important element in marketing fresh lychee fruit, and few commercial cultivars have sufficiently large fruit (Goren and Gazit, 1996; Menzel and Simpson, 1990, 1991). Nevertheless, we are aware of no reports or methods for increasing lychee fruit size. Although fruit thinning can increase fruit size in many crops, it often reduces yield (Guardiola et al., 1982; Wheaton, 1981; Zaragoza et al., 1992). Several synthetic auxins increase fruit size in citrus (Gallasch, 1988; Monselise, 1977, 1978; Ortola et al., 1991), and TPA, formulated as an isopropyl ester (Agusti et al., 1994, 1995) or as a free acid [Maxim ${ }^{\circledR}$ (Agusti et al., 1993)], increases citrus fruit size without reducing fruit number.

Lychee tends to have massive fruitlet drop. Spraying with the auxin TP (as Tipimon ${ }^{\circledR}$ ) greatly reduces the drop and increases the yield of 'Mauritius' and 'Floridian', without reducing fruit weight (Stern et al., 1995, 1997). The optimal time for spraying is when fruitlet weight is $\approx 2 \mathrm{~g}$ ('Mauritius'), and 1-2 $\mathrm{g}$ ('Floridian') (Stern et al., 1995, 1997). Consequently, in the last few years, use of TP has become standard practice in the lychee industry in Israel (Goren and Gazit, 1996). More recently, Stern and Gazit (1997) found that the synthetic auxin TPA (as Maxim ${ }^{\circledR}$ )

Received for publication 9 Mar. 1999. Accepted for publication 27 Oct. 1999. The cost of publishing this paper was defrayed in part by the payment of page charges. Under postal regulations, this paper therefore must be hereby marked advertisement solely to indicate this fact.

${ }^{1}$ E-mail address: Raffi@migal.org.il greatly increased the yield of 'Mauritius' but not of 'Floridian'. It also increased 'Kaimana' yield and fruit weight when applied at the 0.5-g fruitlet stage (Stern and Gazit, 1999).

The following study was conducted to compare the effects of TP and TPA on lychee fruit size in relation to their effects on yield. Some of the trials were designed to test their specific effects on fruit size at a similar fruit load. Their effects on fruit characteristics were also determined.

\section{Materials and Methods}

The trials were conducted in commercial lychee orchards in Israel, with the cultivars Mauritius, Floridian, and Kaimana (Table 1). The trees in each orchard were uniform in size and in initial fruit set.

Two commercial products, containing different synthetic auxins, were applied alone or in combination: 1) Maxim ${ }^{\circledR}$ tablets containing 10\% TPA as a free acid (DowElanco, Madrid, Spain); 2) Tipimon ${ }^{\circledR}$ - a liquid for- mulation containing $6.8 \% \mathrm{TP}$ formulated as a triethanolamine salt (Tapazol, Rishon Lezion, Israel). The TPA was sprayed at 20, 25, and 50 $\mathrm{mg} \cdot \mathrm{L}^{-1}$; $\mathrm{TP}$ at $100 \mathrm{mg} \cdot \mathrm{L}^{-1}\left(0.15 \%\right.$ Tipimon $\left.^{\circledR}\right)$ or $67 \mathrm{mg} \cdot \mathrm{L}^{-1}\left(0.1 \%\right.$ Tipimon $\left.^{\circledR}\right)$ with $0.025 \%$ Triton $\mathrm{X}-100^{\circledR}$

Expts. 1-2: 'Kaimana' trials. Seven- or eight-year-old 'Kaimana' trees, planted at $4 \times$ 5-m spacing were sprayed with a motorized, air-blower, backpack-sprayer (model DM9; Echo, Japan). Because 'Kaimana' does not respond well to TP (Stern and Gazit, 1999) only TPA was applied. The TPA (2 L per tree) was applied at $50 \mathrm{mg} \cdot \mathrm{L}^{-1}$ in 1996 and at 25 or $50 \mathrm{mg} \cdot \mathrm{L}^{-1}$ in 1997,3 weeks after full female bloom (fruitlet weight was $\approx 0.5 \mathrm{~g}$ ). A randomized complete-block design was used with 10 blocks and one tree per block. At harvest, yield per tree was recorded and average fruit weight was determined by weighing 50 randomly sampled fruits per tree.

Expts. 3-5: 'Floridian' trials. Three identical trials were conducted in commercial plots: a young plot planted at $4 \times 5-\mathrm{m}$ spacing in 1989 (Lavi); and two mature plots, planted at $6 \times 6-\mathrm{m}$ spacing in 1979 (Rosh Pina) and 1982 (Kfar Hanasi). Spraying was performed with a commercial 1000-L Spidet blower sprayer. The volume applied was adjusted to tree size $\left(700 \mathrm{~L} \cdot \mathrm{ha}^{-1}\right.$ for the small trees at the young plot in Lavi and $1000 \mathrm{~L} \cdot \mathrm{ha}^{-1}$ for the large trees in the mature plots). Both auxins (100 $\mathrm{mg} \cdot \mathrm{L}^{-1} \mathrm{TP}$ and 25 or $50 \mathrm{mg} \cdot \mathrm{L}^{-1} \mathrm{TPA}$ ) were applied when fruitlets weighed $\approx 1 \mathrm{~g}$ (Stern et al., 1997). The experimental design consisted of four randomized blocks with 200 (four blocks $\times 50$ trees) trees per treatment. Fruit size was determined only in Lavi. All fruits from 20 trees (four blocks $\times$ five trees) per treatment were sorted in the packinghouse.

Expts. 6-8: 'Mauritius' and 'Floridian' trials. Three separate trials were conducted in mixed 'Mauritius' and 'Floridian' plots. The trials were designed to determine the effect of an additional spraying with TPA, applied 1 week after the recommended spraying with TP. The standard spraying was performed at the same time, but while fruitlets of 'Mauritius' weighed $\approx 2 \mathrm{~g}$, those of the late-blooming 'Floridian' weighed $\approx 1 \mathrm{~g}$.

In 1997, three treatments were applied in Lavi: the standard $100 \mathrm{mg} \cdot \mathrm{L}^{-1} \mathrm{TP}, 20 \mathrm{mg} \cdot \mathrm{L}^{-1}$ TPA, and a double application of $100 \mathrm{mg} \cdot \mathrm{L}^{-1}$ TP followed by $20 \mathrm{mg} \cdot \mathrm{L}^{-1}$ TPA a week later. The experimental design consisted of four randomized blocks with 200 (four blocks $\times 50$ trees) trees per treatment for each cultivar. Yield data were collected from all experimen-

Table 1. Experimental conditions for evaluating effects of TP and TPA on lychee fruit development.

\begin{tabular}{lcccccrr}
\hline & & \multicolumn{2}{c}{ Year } & & & \multicolumn{2}{c}{ Concn $\left(\mathrm{mg} \cdot \mathrm{L}^{-1}\right)$} \\
\cline { 3 - 5 } Expt. & Cultivar & Planted & Treated & Location & Spacing $(\mathrm{m})$ & TP & TPA \\
\hline 1 & Kaimana & 1989 & 1996 & Lavi & $4 \times 5$ & 0 & 50 \\
2 & Kaimana & 1989 & 1997 & Lavi & $4 \times 5$ & 0 & 25,50 \\
3 & Floridian & 1989 & 1996 & Lavi & $4 \times 5$ & 100 & 25,50 \\
4 & Floridian & 1979 & 1996 & Rosh-Pina & $6 \times 6$ & 100 & 25,50 \\
5 & Floridian & 1982 & 1996 & Kfar-Hanasi & $6 \times 6$ & 100 & 25,50 \\
6 & Mauritius + Floridian & 1989 & 1997 & Lavi & $4 \times 5$ & 100 & 20 \\
7 & Mauritius + Floridian & 1982 & 1997 & Lavi & $6 \times 6$ & 100 & 20 \\
8 & Mauritius + Floridian & 1989 & 1998 & Lavi & $4 \times 5$ & 67 & 20 \\
\hline
\end{tabular}


Table 2. Effects of application of 3,5,6-TPA, with or without 2,4,5-TP, on yield and weight of marketable fruit $(>15 \mathrm{~g})$.

\begin{tabular}{|c|c|c|c|c|c|}
\hline \multicolumn{2}{|c|}{ Treatment } & \multicolumn{2}{|c|}{ Yield } & \multicolumn{2}{|c|}{ Fruit wt } \\
\hline $\begin{array}{l}\mathrm{TP} \\
\left(\mathrm{mg} \cdot \mathrm{L}^{-1}\right)\end{array}$ & $\begin{array}{l}\text { TPA } \\
\left(\mathrm{mg} \cdot \mathrm{L}^{-1}\right)\end{array}$ & $\left(\mathrm{t} \cdot \mathrm{ha}^{-1}\right)$ & $\begin{array}{c}\text { Increase } \\
(\%)\end{array}$ & (g) & $\begin{array}{c}\text { Increase } \\
(\%)\end{array}$ \\
\hline \multicolumn{6}{|c|}{ Expt. 1 'Kaimana', 1996' } \\
\hline 0 & 0 & $4.1 \mathrm{~b}^{\mathrm{y}}$ & --- & $28.5 \mathrm{~b}$ & --- \\
\hline 0 & 50 & $8.4 \mathrm{a}$ & 104 & $32.3 \mathrm{a}$ & 14 \\
\hline \multicolumn{6}{|c|}{ Expt. 2 'Kaimana', 1997 } \\
\hline 0 & 0 & $0.9 \mathrm{~b}$ & -- & $30.3 \mathrm{~b}$ & --- \\
\hline 0 & 25 & $2.5 \mathrm{a}$ & 177 & $36.7 \mathrm{a}$ & 21 \\
\hline 0 & 50 & $2.4 \mathrm{a}$ & 167 & $36.3 \mathrm{a}$ & 19 \\
\hline \multicolumn{6}{|c|}{ Expt. 7 'Mauritius', 1997} \\
\hline 100 & 0 & $16 \mathrm{~b}$ & --- & $23.7 \mathrm{~b}$ & --- \\
\hline 100 & $20^{\mathrm{x}}$ & $19 \mathrm{a}$ & 19 & $27.0 \mathrm{a}$ & 14 \\
\hline \multicolumn{6}{|c|}{ Expt. 7 'Floridian', 1997} \\
\hline 100 & 0 & $8 \mathrm{a}$ & --- & $23.0 \mathrm{~b}$ & --- \\
\hline 100 & $20^{x}$ & $10 \mathrm{a}$ & 25 & $27.8 \mathrm{a}$ & 20 \\
\hline
\end{tabular}

${ }^{2}$ Treatment applied at the 0.5 -g fruitlet stage. Data for yield are means for 10 replicate trees per treatment. Data on fruit weight are means for 50 fruits per tree (Expts. 1-2).

${ }^{y}$ Mean separation within columns, years and cultivars by Duncan's multiple range test, $P \leq 0.05$. ${ }^{x}$ TPA applied one week after TP. Data for yield are means of 40 trees per treatment (four blocks $\times 10$ trees). Data for fruit weight are means of 300 fruits per treatment ( 50 fruits/tree $\times$ six trees with similar yield per treatment). (Expt. 7).

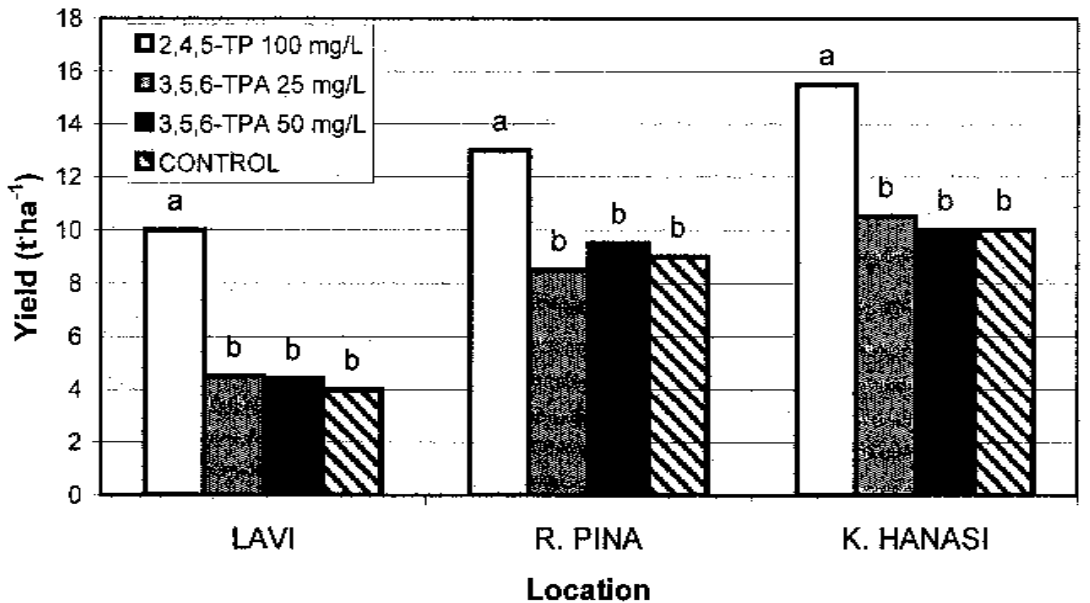

Fig. 1. Effects of application of 2,4,5-TP $\left(100 \mathrm{mg} \cdot \mathrm{L}^{-1}\right)$ and 3,5,6-TPA (25 and $\left.50 \mathrm{mg} \cdot \mathrm{L}^{-1}\right)$ on yield of marketable fruit (>12 g) in 'Floridian' lychee orchards at Lavi, Rosh Pina, and Kfar Hanasi in 1996. Data are the means of 200 trees/treatment (four replicates $\times 50$ trees). Mean separation within orchards by Duncan's multiple range test, $P \leq 0.05$. (Expts. $3-5$ ).

Table 3. Effects of 3,5,6-TPA, with or without 2,4,5-TP, on fruit size distribution of 'Mauritius' and 'Floridian' lychee fruit. Data are means for fruit harvested from 20 trees per treatment (four blocks $\times$ five trees). The experiment was conducted at the young plot in Lavi in 1996 (Expt. 3) and 1997 (Expt. 6).

\begin{tabular}{|c|c|c|c|c|c|c|}
\hline \multicolumn{2}{|c|}{ Treatment } & & & & & \multirow{3}{*}{$\begin{array}{c}\text { Yield } \\
\text { (kg/tree) }\end{array}$} \\
\hline \multirow{2}{*}{$\begin{array}{l}\mathrm{TP} \\
\left(\mathrm{mg} \cdot \mathrm{L}^{-1}\right)\end{array}$} & \multirow{2}{*}{$\begin{array}{c}\text { TPA } \\
\left(\mathrm{mg} \cdot \mathrm{L}^{-1}\right)\end{array}$} & \multicolumn{4}{|c|}{ Fruit distribution (\%) } & \\
\hline & & $\overline{<25 \mathrm{~mm}^{2}}$ & $26-30 \mathrm{~mm}$ & $31-35 \mathrm{~mm}$ & $>36 \mathrm{~mm}$ & \\
\hline \multicolumn{7}{|c|}{ Expt. 3 'Floridian', 1996} \\
\hline 0 & 0 & $2 b^{y}$ & $25 \mathrm{~b}$ & $27 \mathrm{a}$ & $46 \mathrm{~b}$ & $7.9 \mathrm{~b}$ \\
\hline 100 & 0 & $16 \mathrm{a}$ & $33 \mathrm{a}$ & $22 \mathrm{a}$ & $29 \mathrm{c}$ & $18.8 \mathrm{a}$ \\
\hline 0 & 25 & $3 \mathrm{~b}$ & $10 \mathrm{c}$ & $22 \mathrm{a}$ & $65 \mathrm{a}$ & $8.1 \mathrm{~b}$ \\
\hline 0 & 50 & $2 b$ & $9 \mathrm{c}$ & $26 \mathrm{a}$ & $63 \mathrm{a}$ & $8.0 \mathrm{~b}$ \\
\hline \multicolumn{7}{|c|}{ Expt. 6 'Mauritius', 1997} \\
\hline 0 & 0 & $1 \mathrm{~b}$ & $42 \mathrm{a}$ & $34 \mathrm{~b}$ & $23 \mathrm{~b}$ & $21.0 \mathrm{a}$ \\
\hline 100 & 0 & $2 \mathrm{ab}$ & $20 \mathrm{~b}$ & $52 \mathrm{a}$ & $26 \mathrm{~b}$ & $21.6 \mathrm{a}$ \\
\hline 0 & 20 & $2 \mathrm{ab}$ & $4 \mathrm{c}$ & $40 \mathrm{~b}$ & $49 \mathrm{a}$ & $20.7 \mathrm{a}$ \\
\hline 100 & 20 & $3 a$ & $10 \mathrm{c}$ & $37 \mathrm{~b}$ & $51 \mathrm{a}$ & $18.9 \mathrm{a}$ \\
\hline \multicolumn{7}{|c|}{ Expt. 6 'Floridian', 1997} \\
\hline 0 & 0 & $1 \mathrm{c}$ & $46 \mathrm{a}$ & $38 \mathrm{a}$ & $15 \mathrm{c}$ & $11.0 \mathrm{a}$ \\
\hline 100 & 0 & $16 \mathrm{a}$ & $16 \mathrm{c}$ & $45 \mathrm{a}$ & $23 \mathrm{c}$ & $11.3 \mathrm{a}$ \\
\hline 0 & 20 & $2 \mathrm{c}$ & $10 \mathrm{c}$ & $41 \mathrm{a}$ & $47 \mathrm{a}$ & $10.8 \mathrm{a}$ \\
\hline 100 & 20 & $8 \mathrm{~b}$ & $26 \mathrm{~b}$ & $33 \mathrm{a}$ & $33 \mathrm{~b}$ & $11.9 \mathrm{a}$ \\
\hline
\end{tabular}

${ }^{2}$ Average weight: $<25 \mathrm{~mm}=12 \mathrm{~g}$ (below standard size/unmarketable fruit); 26-30 mm = $18 \mathrm{~g} ; 31-35 \mathrm{~mm}$ $=23 \mathrm{~g} ;>36 \mathrm{~mm}=28 \mathrm{~g}$.

${ }^{y}$ Mean separation within columns, year, and cultivars, by Duncan's multiple range test, $P \leq 0.05$. tal trees, and fruit size data from 20 (four blocks $\times$ five) trees per treatment, which carried typical and similar fruit loads for each cultivar.

In 1997 the mature plot in Lavi (planted in 1982, at 6×6-m spacing) was routinely sprayed with $100 \mathrm{mg} \cdot \mathrm{L}^{-1} \mathrm{TP}$. A week later, the experimental treatment of $20 \mathrm{mg} \cdot \mathrm{L}^{-1} \mathrm{TPA}$ was applied. The experimental design consisted of four randomized blocks, with 40 (four blocks $\times 10)$ trees per treatment, for each cultivar. Fruit weight data are the means of 300 fruits per treatment $(50$ fruits/tree $\times$ six trees) harvested from trees with typical and similar fruit loads for each cultivar.

In 1998 at the young plot in Lavi, we determined the effect of an additional 20 $\mathrm{mg} \cdot \mathrm{L}^{-1} \mathrm{TPA}$ spray on fruit size. The TP treatment was applied at the reduced rate of 67 $\mathrm{mg} \cdot \mathrm{L}^{-1}\left(0.1 \%\right.$ Tipimon $\left.^{\circledR}\right)$. At harvest, only fruit size was measured. Fruit from 20 (four blocks $\times$ five) trees, carrying typical and similar fruit loads, were sorted per treatment for each cultivar.

Weights of the various tissues of the fruits were determined for 50 mature fruits per treatment (10 fruits $\times$ five trees). Each fruit was weighed and then its components (seed, peel, and aril) were weighed. The level of total soluble solids (TSS) in the aril was measured with a refractometer.

Statistical analysis. Percentage data were subjected to arcsin transformation before analysis to provide for a normal distribution. Data were analyzed for statistical significance using the general linear model (GLM) procedure. Duncan's multiple range test was used to compare treatments when analysis of variance showed a significant difference among the means.

\section{Results}

Expts. 1-2: 'Kaimana' Trials. In 1997, the trees suffered from frost in February and a rare cold spell in April, thus, yield was much lower than in 1996. Nevertheless, in both years, spraying with TPA significantly increased yield and fruit weight (Table 2).

Expts. 3-5: 'Floridian' trials. In all three trials, TP significantly increased yield, whereas TPA did not (Fig. 1). However, we were surprised by the larger fruit produced in all TPAtreated plots, an observation that could be quantified in only one location (Lavi). Treatment with TPA significantly increased the percentage of large fruit ( $>36 \mathrm{~mm}$ in diameter) from $46 \%$ in the control trees to $\approx 64 \%$ in TPAtreated trees (Table 3 ). In contrast, TP significantly increased marketable fruit $(>12 \mathrm{~g})$ yield, by $140 \%$ (Fig. 1), but also significantly increased the percentage of small $(<25 \mathrm{~mm})$ and medium fruit $(26-30 \mathrm{~mm})$, while reducing the percentage of large fruit (Table 3).

Expts. 6-8: 'Mauritius' and 'Floridian' trials. The effects on yield of each of the two synthetic auxins alone were as expected (Stern and Gazit, 1997; Stern et al., 1995, 1997). TP significantly increased the yield of both 'Mauritius' and 'Floridian', whereas TPA increased yield only in 'Mauritius' (Fig. 2). The additional TPA spray resulted in a signifi- 
Table 4. Effects of application of 2,4,5-TP and 3,5,6-TPA on young 'Mauritius' and 'Floridian' lychee trees on fruit characteristics and seed weight distribution in the young plot at Lavi at 1997 (Expt. 6). Data are the means of 50 fruits per treatment (10 fruits/tree $\times$ five trees with similar yield).

\begin{tabular}{|c|c|c|c|c|c|c|c|c|c|c|c|}
\hline \multicolumn{2}{|c|}{ Treatment } & \multicolumn{6}{|c|}{ Fruit characteristics } & & & & \\
\hline & TPA & Fruit wt & Peel wt & Aril wt & Seed wt & Seed/fruit & TSS & \multicolumn{4}{|c|}{ Seed distribution $(\%)$} \\
\hline$\left(\mathrm{mg} \cdot \mathrm{L}^{-1}\right)$ & $\left(\mathrm{mg} \cdot \mathrm{L}^{-1}\right)$ & (g) & (g) & (g) & (g) & $(\%)$ & $(\%)$ & $<1 \mathrm{~g}$ & $1.1-2.5 \mathrm{~g}$ & $2.6-4.0 \mathrm{~g}$ & $>4.1 \mathrm{~g}$ \\
\hline \multicolumn{12}{|c|}{ Mauritius } \\
\hline 0 & 0 & $23.0 \mathrm{~b}^{\mathrm{z}}$ & $2.3 \mathrm{~b}$ & $17.4 \mathrm{~b}$ & $3.3 \mathrm{~b}$ & $14.3 \mathrm{~b}$ & $19.1 \mathrm{a}$ & $4 \mathrm{~b}$ & $8 \mathrm{ab}$ & $80 \mathrm{a}$ & $8 \mathrm{c}$ \\
\hline 100 & 0 & $23.0 \mathrm{~b}$ & $2.2 \mathrm{~b}$ & $18.0 \mathrm{~b}$ & $2.8 \mathrm{~b}$ & $12.1 \mathrm{c}$ & $19.2 \mathrm{a}$ & $20 \mathrm{a}$ & $16 \mathrm{a}$ & $52 \mathrm{~b}$ & $12 \mathrm{c}$ \\
\hline 0 & 20 & $28.0 \mathrm{a}$ & $2.8 \mathrm{a}$ & $21.0 \mathrm{a}$ & $4.2 \mathrm{a}$ & $15.0 \mathrm{a}$ & $19.0 \mathrm{a}$ & $4 \mathrm{~b}$ & $0 \mathrm{~b}$ & $38 \mathrm{~b}$ & $58 \mathrm{a}$ \\
\hline 100 & 20 & $27.5 \mathrm{a}$ & $2.8 \mathrm{a}$ & $20.9 \mathrm{a}$ & $3.8 \mathrm{a}$ & $13.8 \mathrm{~b}$ & $19.2 \mathrm{a}$ & $14 \mathrm{ab}$ & $0 \mathrm{~b}$ & $40 \mathrm{~b}$ & $46 \mathrm{~b}$ \\
\hline \multicolumn{12}{|c|}{ Floridian } \\
\hline 0 & 0 & $23.2 \mathrm{c}$ & $2.2 \mathrm{c}$ & $17.9 \mathrm{c}$ & $3.1 \mathrm{~b}$ & $13.4 \mathrm{a}$ & $18.9 \mathrm{a}$ & $14 \mathrm{c}$ & $10 \mathrm{a}$ & $62 \mathrm{a}$ & $14 \mathrm{~b}$ \\
\hline 100 & 0 & $23.2 \mathrm{c}$ & $2.2 \mathrm{c}$ & $18.4 \mathrm{bc}$ & $2.6 \mathrm{~b}$ & $11.2 \mathrm{~b}$ & $19.1 \mathrm{a}$ & $30 \mathrm{a}$ & $12 \mathrm{a}$ & $48 \mathrm{a}$ & $10 \mathrm{~b}$ \\
\hline 0 & 20 & $27.8 \mathrm{a}$ & $2.7 \mathrm{a}$ & $21.4 \mathrm{a}$ & $3.7 \mathrm{a}$ & $13.3 \mathrm{a}$ & $19.3 \mathrm{a}$ & $12 \mathrm{c}$ & $0 \mathrm{a}$ & $40 \mathrm{a}$ & $48 \mathrm{a}$ \\
\hline 100 & 20 & $24.4 \mathrm{~b}$ & $2.4 \mathrm{~b}$ & $19.1 \mathrm{~b}$ & $2.9 \mathrm{~b}$ & $11.9 \mathrm{~b}$ & $18.9 \mathrm{a}$ & $24 \mathrm{~b}$ & $4 \mathrm{a}$ & $56 \mathrm{a}$ & $16 \mathrm{~b}$ \\
\hline
\end{tabular}

${ }^{\mathrm{z}}$ Mean separation within columns and cultivars by Duncan's multiple range test, $P \leq 0.05$.

cantly higher yield; for 'Mauritius' and 'Floridian', the increase reached $220 \%$ and $83 \%$ of the control, and $130 \%$ and $75 \%$ of the standard TP treatment, respectively.

To separate the effects of these treatments on yield from their effects on fruit size, we identified 20 trees in each block that were similar in size and yield, five for each of the four treatments. The fruit was sorted by diameter in a commercial grading machine. For trees with the same crop load, TPA doubled the percentage of large fruit $(>36$ $\mathrm{mm}$ diameter) in 'Mauritius' and tripled it in 'Floridian' (Table 3). In 'Mauritius', the combination of TP and TPA produced the same significant increase, whereas in 'Floridian' the increase was significantly less. In 'Floridian', TP increased the percentage of small (i.e., below standard size) fruit, but TPA did not.

Spraying $20 \mathrm{mg} \cdot \mathrm{L}^{-1}$ TPA a week after the standard spraying of $100 \mathrm{mg} \cdot \mathrm{L}^{-1} \mathrm{TP}$ significantly increased 'Mauritius' yield by $19 \%$, but the increase in 'Floridian' was nonsignificant (Table 2). This treatment also significantly increased fruit weight $14 \%$ and $20 \%$, in 'Mauritius' and 'Floridian', respectively.

Spraying with $20 \mathrm{mg} \cdot \mathrm{L}^{-1} \mathrm{TPA}$ a week after a substandard spray of $67 \mathrm{mg} \cdot \mathrm{L}^{-1}$ TP (1998) significantly increased the percentage of large fruit ( $>36 \mathrm{~mm}$ ) from $7 \%$ to $42 \%$ for 'Mauritius' trees carrying $15.5 \mathrm{~kg} /$ tree $\left(8 \mathrm{t} \cdot \mathrm{ha}^{-1}\right)$, and from $1 \%$ to $25 \%$ for 'Floridian trees with $31 \mathrm{~kg} /$ tree $\left(16 \mathrm{t} \cdot h \mathrm{~h}^{-1}\right)$.

In both cultivars, TPA alone significantly increased the weight of all three fruit tissues (Table 4). When applied after TP, it had a similar effect on 'Mauritius' and a somewhat lesser effect on 'Floridian'. No significant effect on TSS in the aril was noted.

TPA dramatically increased the percentage of heavy seeds (over $4.1 \mathrm{~g}$ ). In contrast, TP significantly increased the percentage of small, degenerated seeds.

Seed and fruit weight were significantly correlated in 'Mauritius' and 'Floridian' for fruits with viable seeds $(>1 \mathrm{~g})$. The correlation was very high for control fruit of both cultivars $\left(R^{2}=0.95\right.$ and 0.93 for 'Mauritius' and 'Floridian', respectively), and for 'Mauritius' fruit from the TP treatment $\left(R^{2}=0.95\right)$. The data for fruit from the TPA treatment were

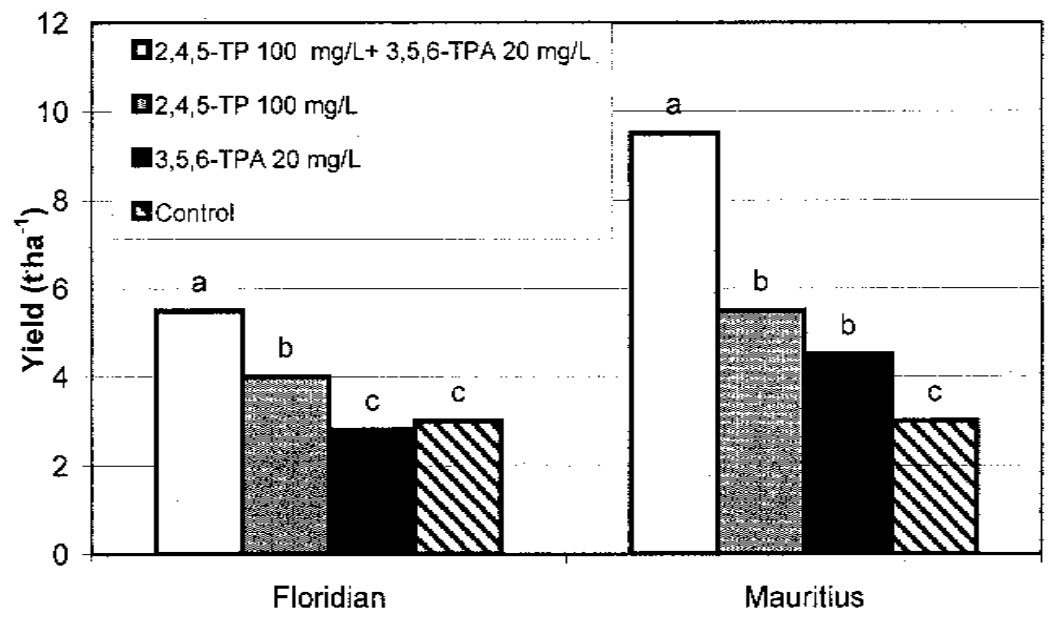

Fig. 2. Effects of application of 2,4,5-TP $\left(100 \mathrm{mg} \cdot \mathrm{L}^{-1}\right), 3,5,6-\mathrm{TPA}\left(20 \mathrm{mg} \cdot \mathrm{L}^{-1}\right)$, or a combination of the two (see Materials and Methods) on yield of marketable fruit $(>12 \mathrm{~g})$ in a young 'Mauritius' and 'Floridian' lychee plot at Lavi (1997). Data are the means of 200 trees/treatment (four replicates $\times 50$ trees). Mean separation within cultivars by Duncan's multiple range test, $P \leq 0.05$. (Expt. 6).

much more scattered $\left(R^{2}=0.66\right.$ and 0.58 for 'Mauritius' and 'Floridian', respectively).

\section{Discussion}

The effects of TP and TPA on 'Mauritius', 'Floridian', and 'Kaimana' yields confirmed our previous findings (Stern and Gazit, 1997, 1999; Stern et al., 1995, 1997). TP significantly increased 'Mauritius' and 'Floridian' yields, and TPA significantly increased 'Mauritius' and 'Kaimana' yield, with no appreciable effect on 'Floridian' (Fig. 1, Fig. 2 , Table 2). Thus, different lychee cultivars may respond differently to synthetic auxins, emphasizing the need to study the response of each cultivar to each particular auxin.

Application of TP followed by TPA was more effective in increasing yield than was application of either auxin alone (Fig. 2, Table 2). The yield increase was pronounced for young trees, with a light yield of $\approx 2 \mathrm{t} \cdot \mathrm{ha}^{-}$ ${ }^{1}$; it was much smaller, but still significant, for mature trees, with a good yield of $8 \mathrm{t} \cdot \mathrm{ha}^{-}$ ${ }^{1}$ and $16 \mathrm{t} \cdot \mathrm{ha}^{-1}$ for TP-treated 'Floridian' and 'Mauritius', respectively. The increased yield was apparently a result of increased fruit weight and a reduction in fruitlet drop, espe- cially in 'Mauritius'. These positive results warrant further studies to find the optimal concentrations and timing for this combination treatment.

TPA consistently increased lychee fruit size relative to fruit from control or TPtreated trees (Tables 2-4). The increase was more evident when yield was similar for control and TPA-treated trees (Table 3). It was still significant (14\%-21\% increase), even when TPA significantly increased yield in 'Kaimana' (Table 2). We did not find an appreciable increase in 'Mauritius' fruit size in our previous study (Stern and Gazit, 1997); apparently, a considerable increase in yield prevented the increase in size.

TP reduces the drop of fruit with degenerated seeds (Stern et al., 1995, 1997). In the current study, it significantly increased the percentage of small fruit in 'Floridian' (Table 3 ), and the percentage of fruit with degenerated seeds in 'Mauritius' and 'Floridian' (Table 4). In contrast, TPA did not prevent the abscission of these fruits.

The increase in lychee fruit size following TPA treatment cannot be explained by fruit thinning, as suggested for citrus (Guardiola et al., 1982; Wheaton, 1981; Zaragoza et al., 
1992) and apple (Dennis, 1986). The treatment probably makes the fruit a stronger sink (Agusti et al., 1995; Mauk et al., 1986). The significant increase in seed weight (Table 4) apparently reflects this effect. The weight increase in all of the fruit's tissues (peel, aril, and seed) did not reduce TSS in the aril (Table 4). Hence, at this crop load the fruit still has access to sufficient nutrients.

\section{Literature Cited}

Agusti, M., V. Almela, M. Juan, M. Aznar, S. Zaragoza, and E. Primo-Millo. 1993. Aplicacion de TPA para aumentar el tamano del fruto en los agrios. Lavante Agricola 323:117-126.

Agusti, M., V. Almela, M. Juan, E. Primo-Millo, I. Trenor, and S. Zaragoza. 1994. Effect of 3,5,6trichloro-2-pyridyl-oxyacetic acid on fruit size and yield of 'Clausellina' mandarin (Citrus unshiu Marc.). J. Hort. Sci. 69:219-223.

Agusti, M., M. El-Otmani, M. Aznar, M. Juan, and V. Almela. 1995. Effect of 3,5,6-trichloro-2pyridyl-oxyacetic acid on clementine early fruitlet development and on fruit size at maturity. J. Hort. Sci. 70:955-962.

Dennis, F.G., Jr. 1986. Apple, p. 1-44. In: S.P. Monselise (ed.). Handbook of fruit set and development. CRC Press, Boca Raton, Fla.

Gallasch, P.T. 1988. Chemical thinning of heavy crops of mandarins to increase fruit size. Proc. 6th Intl. Citrus Congr. 1:395-405.

Goren, M. and S. Gazit. 1996. Israel's lychee industry, with special emphasis on cultivars and breeding, p. 31-35. In: Proc. 4th Natl. Lychee and Longan Seminar, Yeppoon, Australia.

Guardiola, J.L., M. Agusti, F. Garcia-Mari, and V. Almela. 1982. The regulation of fruit size in citrus by tree factors. Proc. XXIst Intl. Hort. Congr. 1:1363. (Abstr.)

Mauk, C.S., M.G. Bausher, and G. Yelenosky. 1986. Influence of growth regulator treatments on dry matter production, fruit abscission, and ${ }^{14} \mathrm{C}$-assimilate partitioning in citrus. J. Plant Growth Regulat. 5:111-120.

Menzel, C.M. and D.R. Simpson. 1990. Performance and improvement of lychee cultivars: A review. Fruit Var. J. 44:197-215.

Menzel, C.M. and D.R. Simpson. 1991. Lychee cultivars around the world. Australian Lychee Yrbk. 1:30-34.

Monselise, S.P. 1977. Citrus fruit development: Endogenous systems and external regulation. Proc. Intl. Soc. Citricult. 2:664-669.

Monselise, S.P. 1978. Understanding of plant processes as a basis for successful growth regulation in citrus. Proc. Intl. Soc. Citricult. 3:250-255.

Ortola, A.G., C. Monerri, and J.L. Guardiola. 1991. The use of naphthalene acetic acid as a fruit growth enhancer in Satsuma mandarin: A comparison with the fruit thinning effect. Scientia Hort. 47:15-25.

Stern, R.A. and S. Gazit. 1997. Effect of 3,5,6trichloro-2-pyridyl-oxyacetic acid on fruitlet abscission and yield of 'Mauritius' lychee (Lychee chinensis Sonn.). J. Hort. Sci. 72:659-663.

Stern, R.A. and S. Gazit. 1999. The synthetic auxin TPA reduces fruit drop and increases yield in 'Kaimana' lychee. J. Hort. Sci. and Biotech. 74:203-205.

Stern, R.A., J. Kigel, E. Tomer, and S. Gazit. 1995. 'Mauritius' lychee fruit development and reduced abscission after treatment with the auxin TP. J. Amer. Soc. Hort. Sci. 120:65-70.

Stern, R.A., M. Nadler, and S. Gazit. 1997. 'Floridian' lychee yield is increased by TP spray. $\mathrm{J}$. Hort. Sci. 72:609-615.

Wheaton, T.A. 1981. Fruit thinning of Florida mandarin using plant growth regulators. Proc. Intl. Soc. Citricult. 6:263-268.

Zaragoza, S., I. Trenor, E. Alonso, E. Primo-Millo, and M. Agusti. 1992. Treatment to increase the final fruit size of satsuma Clausellina. Proc. Intl. Soc. Citricult. 2:725-728. 